\title{
IMBANGAN HIJAUAN DAN KONSENTRAT DALAM RANSUM TERHADAP RESPON FERMENTASI RUMEN DAN SINTESIS PROTEIN MIKROBA PEDET SAPI BALI CALON INDUK
}

\author{
BUDIASA, I K. M., N. N. SURYANI, DAN I W. SUARNA \\ Fakultas Peternakan Universitas Udayana \\ e-mail: mangkubudiasa@unud.ac.id
}

\begin{abstract}
ABSTRAK
Guna memenuhi kebutuhan daging dalam negeri dan mengurangi import, pemerintah terus berupaya mengembangkan bibit sapi lokal baik kuantitas maupun kualitas. Diantara sapi lokal yang diternakkan di Indonesia, sapi bali paling diminati (32,31\%). Penelitian menggunakan pedet sapi bali calon induk sebanyak 12 ekor dengan berat badan $\pm 100 \mathrm{~kg}$. Empat jenis ransum merupakan imbangan antara hijauan dan konsentrat dipergunakan sebagai perlakuan yaitu: konsentrat 40\% : rumput raja 60\% (perlakuan A); konsentrat $45 \%$ : rumput raja $55 \%$ (perlakuan B); konsentrat 50\% : rumput raja 50\% (perlakuan C) : konsentrat 55\% dan rumput raja 45\% (perlakuan D). Rancangan yang digunakan adalah rancangan acak kelompok (RAK). Peubah yang diamati adalah proses fermentasi rumen antara lain: $\mathrm{pH}, \mathrm{NH}_{3}$, VFA total dan partial (asam asetat, propionat dan butirat), sistesis protein mikroba dan jumlah protozoa. Hasil penelitian menunjukkan, perlakun D menghasilkan $\mathrm{NH}_{3}$ dan VFA Total tertinggi masing-masing 14,66 mMol dan 165,38 mMol dibanding semua perlakuan lainnya. Asam propionat juga tertinggi pada perlakuan D yaitu 27,87 mMol dan sintesis protein mikroba (SPM) 368,62 g/e/h. Berdasarkan hasil penelitian ini dapat disimpulkan, semakin tinggi proporsi konsentrat dalam ransum pedet sapi bali calon induk maka semakin banyak sumber energi yang tersedia sehingga pasokan SPM untuk hewan inang semakin tinggi.
\end{abstract}

Kata kunci: imbangan, fermentasi rumen, sintesis protein mikroba dan populasi protozoa

$$
\begin{aligned}
& \text { THE EFFECT OF FORAGE AND CONCENTRATE IN DIETS TO RESPOND RUMEN } \\
& \text { FERMENTATION AND MICROBIAL PROTEIN SYNTHESIS OF BALI HEIFER CALVES }
\end{aligned}
$$

\begin{abstract}
In order to fulfill the domestic meat requirements and reduce imports so government continually develop local beef cattle based on their quantity and quality of meat. Among the local cattle in Indonesia, Bali cattle is the most favourite cattle (32.31\%) considering on its meat quality. There were 12 calves used in this research with $100 \mathrm{~kg}$ of average body weight. The treatments were diet with $40 \%$ concentrate and $60 \%$ king grass (A); $45 \%$ concentrate and $55 \%$ king grass (B); $50 \%$ concentrate and 50\% king grass (C); $55 \%$ concentrate and $45 \%$ king grass (D). The experiment was design in a completely randomized block design with four treatments and three replicates. The variables measured were rumen fermentation as of $\mathrm{pH}, \mathrm{NH} 3$, total and pastial of VFA (acetic acid, propionic acid and butyric acid), microbial protein synthesis and protozoa populations. It showed that treatment D produce the highest $\mathrm{NH}_{3}$ and total VFA, $14.66 \mathrm{mMol}$, and $165.38 \mathrm{mMol}$ respectively compared to other treatments. Propionic acid was $27.87 \mathrm{mMol}$ the highest in treatment D and $368.62 \mathrm{~g} / \mathrm{h} / \mathrm{d}$ microbial protein synthesis. It can be concluded the higher proportion of concentrate in the bali heifer calves so the more energy supply, in this case, SPM availability for the host animal is higher.
\end{abstract}

Key words: ratio, rumen fermentation, microbial protein synthesis, protozoa population

\section{PENDAHULUAN}

Kementerian Pertanian meluncurkan program upaya khusus percepatan populasi sapi dan kerbau bunting (Upsus Siwab) sebagai upaya untuk mengakselerasi percepatan target pemenuhan populasi sapi potong dalam negeri. Program tersebut dituangkan dalam peraturan Menteri Pertanian Nomor 48/Permentan/ PK.210/10/2016 tentang Upaya Khusus Percepatan Peningkatan Populasi Sapi dan Kerbau Bunting yang 
ditandatangani Menteri Pertanian pada tanggal 3 Oktober 2016. Upsus Siwab bertujuan memaksimalkan potensi sapi indukan di dalam negeri untuk dapat terus menghasilkan pedet. Program ini menjadi fokus Direktorat Jenderal Peternakan dan Kesehatan Hewan pada2017mendatang. Upayainidilakukansebagaiwujud komitmen pemerintah dalam mengejar swasembada sapi yang ditargetkan Presiden Joko Widodo tercapai pada 2026 mendatang serta mewujudkan Indonesia yang mandiri dalam pemenuhan pangan asal hewan dan sekaligus meningkatkan kesejahteraan peternak rakyat.

Umumnya pakan ternak ruminansia terdiri dari hijauan dan konsentrat. Imbangan hijauan dan konsentrat dalam ransum sangat menentukan substrat yang tersedia bagi mikroorganisme di dalam rumen. Aktivitas mikroba di dalam rumen merupakan keunggulan ternak ruminansia yang menyebabkan ternak ruminansia mempunyai kemampuan mengubah protein pakan kualitas rendah menjadi protein mikroba yang bermutu tinggi. Rumen merupakan ekosistem yang kompleks tempat pakan difermentasi oleh bermacam-macam mikroba (bakteri, protozoa dan fungi) yang menghuni di dalamnya. Produk fermentasi rumen terutama Volatile Fatty Acids (VFA) dan biomassa mikroba akan dipergunakan sebagai sumber energi dan protein oleh ternak.

Mikroba rumen merupakan faktor kunci keberhasilan ternak dalam memanafaatkan pakan yang diberikan. Peningkatan populasi mikroba terutama bakteri, selain meningkatkan kecernaan pakan serat, juga merupakan sumber protein berkualitas tinggi bagi ternak ruminansia. Protein mikroba dapat menyumbangkan sampai 90\% kebutuhan asam amino untuk ternak ruminansia (Russell et al., 2009). Lebih lanjut dikatakan, asam amino protein mikroba sangat konsisten dan sangat ideal untuk memenuhi kebutuhan sapi. Oleh karena itu, kecukupan dan keseimbangan nutrien dalam rumen penting untuk memacu pertumbuhan mikroba rumen yang maksimal.

Mullik (2007) menyatakan, besarnya suplai protein dari mikroba rumen merupakan faktor penting untuk memprediksi respons ternak ruminansia terhadap jenis pakan yang diberikan. Menurut Karsli dan Russell (2001), faktor-faktor yang mempengaruhi sintesis protein mikroba rumen adalah konsumsi bahan kering, nisbah hijauan : konsentrat dalam ransum, laju degradasi protein dan karbohidrat, sinkronisasi penyediaan $\mathrm{N}$-protein dan energi, laju alir pakan, vitamin dan mineral. Selanjutnya dijelaskan, ternak yang diberi hijauan sebagai pakan basal, efisiensi sintesis protein mikrobanya rata-rata $13 \mathrm{~g} / \mathrm{kg}$ bahan organik tercerna (BOT). Apabila pakan basal terdiri dari campuran hijauan dan konsentrat, rata-rata efisiensi sintesis protein mikrobanya adalah $17,6 \mathrm{~g} / \mathrm{kg}$ BOT. Pemberian pakan basal yang terdiri dari konsentrat saja, efisiensi sintesis protein mikrobanya 13,2 g/kg BOT.

Berdasarkan uraian di atas, diperlukan strategi untuk mengatur hijauan pakan yang diberikan sesuai dengan karakteristik bahan pakan tersebut, sehingga tercapai keseimbangan nutrien untuk kebutuhan mikroba maupun hewan inang. Penelitian ini bertujuan untuk mengetahui imbangan hijauan dan konsentrat dalam ransum pedet sapi bali betina lepas sapih terhadap: (1) Pola fermentasi rumen pedet sapi bali betina lepas sapih dengan indikator: $\mathrm{pH}$ cairan rumen, metabolit hasil fermentasi rumen seperti konsentrasi $\mathrm{NH}_{3}$ (ammonia), Volatile Fatty Acid (VFA) yang terdiri dari asam asetat, propionate dan butirat., serta non glucogenic ratio (NGR). (2) Mengetahui protein mikroba yang terbentuk berdasarkan imbangan hijauan dan konsentrat yang diberikan. Pada imbangan hijauan konsentrat berapakah terjadi pembentukan protein mikroba trtinggi. (3) Berdasarkan imbangan hijauan konsentrat yang diberikan, akan diamati pula jumlah nutrien yang mampu dicerna oleh mikroba rumen. Semakin tinggi nutrien yang bisa dimanfaatkan oleh mikroba rumen, maka semakin banyak populasi mikroba. Hal ini akan berdampak positif terhadap penyediaan protein untuk hewan inang dari mikroba.

\section{MATERI DAN METODE}

Penelitian menggunakan pedet sapi bali betina lepas sapih dengan berat badan lebih kurang $100 \mathrm{~kg}$. Penelitian dilakukan di Pusat Pembibitan Sapi Bali di Sobangan. Pakan yang diberikan terdiri dari rumput raja dan konsentrat. Air minum yang diberikan berasal dari PDAM. Komposisi ransum dan kandungan nutrien disajikan pada Tabel 1.

Tabel 1. Komposisi ransum percobaan dan kandungan nutrien

\begin{tabular}{lrrrr}
\hline \multirow{2}{*}{ Komposisi \% } & \multicolumn{4}{c}{ Perlakuan } \\
\cline { 2 - 5 } & \multicolumn{1}{c}{ A } & \multicolumn{1}{c}{ B } & \multicolumn{1}{c}{ C } & \multicolumn{1}{c}{ D } \\
\hline Konsentrat & 40.0 & 45.0 & 50.0 & 55.0 \\
Rumput raja & 60.0 & 55.00 & 50.0 & 45.0 \\
Jumlah & 100.0 & 100.0 & 100.0 & 100.0 \\
Kandungan Nutrien & & & & \\
Crude Protein (\%) & 12.00 & 13.00 & 14.00 & 15.00 \\
ME (kcal/kg) & 2000.00 & 2100.00 & 2200.00 & 2300.00 \\
\hline
\end{tabular}

Total waktu yang dibutuhkan untuk penelitian ini selama 6 bulan. Selama satu bulan dilakukan untuk persiapan kandang dan menyusun ransum. Pengamatan data dilakukan selama 3 bulan dan dua bulan sisanya untuk analisis data dan oembuatan laporan.

Pengambilan cairan rumen dilakukan 4 jam setelah ternak sapi diberi makan menggunakan pompa vakum. Cairan rumen yang diperoleh langsung diukur tingkat keasamannya $(\mathrm{pH})$ dengan menggunakan $\mathrm{pH}$ meter. 
Selain pengukuran $\mathrm{pH}$, cairan rumen juga dipakai untuk menghitung populasi bakteri selulolitik, total bakteri, protozoa, N-NH , VFA Total dan VFA Parsial. Cairan rumen setelah diukur $\mathrm{pH}$, dibagi menjadi 2 bagian. Bagian pertama yang akan dipakai untuk menghitung konsentrasi $\mathrm{N}_{-} \mathrm{NH}_{3}$, VFA Total dan VFA Parsial ditetesi dengan $\mathrm{HgCl}_{2}$ jenuh $0,2 \mathrm{ml}$ untuk membunuh mikroba dalam cairan rumen. Bagian kedua yang akan dipakai untuk menghitung populasi protozoa.

Percobaan menggunakan rancangan acak kelompok (RAK) dengan empat jenis ransum yaitu: konsentrat 40\% dan rumput raja 60\% (perlakuan A); konsentrat $45 \%$ dan rumput raja 55\% (perlakuan B); konsentrat 50\% dan rumput raja 50\% (perlakuan C) dan konsentrat 55\% dan rumput raja 45\% (perlakuan D). Empat kelompok pedet lepas sapih dengan berat badan berbeda sebagai ulangan.

\section{Peubah yang diamati.}

Konsentrasi $\mathrm{N}-\mathrm{NH}_{3}$ dan VFA cairan rumen

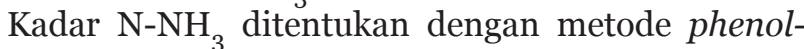
hypochlorite melalui pembacaan dengan Spectrofotometer menurut Solorzano (1969). Sebanyak $15 \mathrm{ml}$ supernatan dimasukkan ke dalam botol yang sudah berisi 5 tetes asam sulfat pekat, kemudian diencerkan 100 kali. Supernatan yang sudah diencerkan ini diambil sebanyak $5 \mathrm{ml}$, dimasukkan ke dalam tabung spektro yang sudah diisi dengan larutan standar. Kemudian ditambahkan berturut-turut $0,2 \mathrm{ml}$ larutan phenol; 0,2 $\mathrm{ml}$ larutan Natrium nitroprusside; dan 0,5 ml larutan pengoksidasi. Pembacaan reaksi warna dilakukan 5 menit setelah penambahan larutan pengoksidasi dengan spektrofotometer.

Pengukuran kadar asam lemak atsiri (VFA) total dilakukan dengan cara penyulingan uap menurut General Laboratory Procedure (1966). Sebanyak 5 ml supernatan dimasukkan ke dalam tabung khusus kemudian ditambahkan $1 \mathrm{ml} \mathrm{H}_{2} \mathrm{SO}_{4} 15 \%$ lalu ditutup. Tabung dihubungkan dengan labu pendingin dan labu yang berisi air lalu dipanaskan. Hasil destilasi ditampung di dalam erlenmeyer yang berisi $5 \mathrm{ml} \mathrm{NaOH}$ 0,5N. Proses destilasi berakhir sampai destilat yang ditampung mencapai volume $\pm 300 \mathrm{ml}$. Tambahkan 1-2 tetes indikator phenolptalin dan dititer dengan $\mathrm{HCl} 0,5 \mathrm{~N}$ sampai terjadi perubahan warna dari merah jambu menjadi tidak berwarna.

VFA total $=(\mathrm{a}-\mathrm{b}) \times \mathrm{N} \mathrm{HCl} \times 1000 / 5 \mathrm{mM}$ $\mathrm{a}=\mathrm{ml} \mathrm{HCl} \mathrm{yang} \mathrm{dibutuhkan} \mathrm{untuk} \mathrm{titrasi} \mathrm{blanko}(5 \mathrm{ml} \mathrm{NaOH})$

$\mathrm{b}=\mathrm{ml} \mathrm{HCl}$ yang dibutuhkan untuk titrasi hasil destilasi

Analisis VFA parsial (asam asetat, propionate, dan butirat) dilakukan dengan teknik gas kromatografi. Sampel cairan rumen disentrifuse dengan kecepatan $10.000 \mathrm{rpm}$ selama 15 menit pada suhu $4^{\circ} \mathrm{C}$ untuk diambil supernatannya. Dua ml supernatan dimasukkan ke dalam tabung plastik kecil tertutup. Ke dalam tabung ditambahkan 50 mg sulphosalicylic acid $\left(\mathrm{C}_{6} \mathrm{H}_{3}(\mathrm{OH}) \mathrm{SO}_{3}\right.$ $2 \mathrm{H}_{2} \mathrm{O}$ ), dikocok hingga homogen. Campuran tersebut lalu disentrifuse selama 10 menit dengan kecepatan 3000 rpm pada suhu $4^{\circ} \mathrm{C}$. Setelah itu disaring dengan melipori sehingga diperoleh cairan jernih. Sebanyak $1 \mathrm{ml}$ cairan tersebut diinjeksikan ke gas kromatografi yang sebelumnya sudah diinjeksi dengan larutan standar VFA (asetat, propionat dan butirat). VFA parsial dihitung dengan rumus:

$$
\text { VFA parsial }(\mathrm{mM})=\frac{\text { Areal sampel }}{\text { Areal standard }} \times \text { konsentrasi standard }
$$

\section{Produksi gas methan menurut Ørskov dan Ryle (1990)}

Methan $=0,5$ Asetat $-0,25$ Propionat + 0,5 Butirat

Non glukogenic ratio (NGR) dihitung berdasarkan rumus Ørskov (1982) :

$$
\text { NGR }=\frac{\text { Asetat }+2 \text { Butirat }}{\text { Propionat }}
$$

\section{Populasi protozoa rumen}

Untuk menghitung jumlah protozoa, cairan rumen dicampur dengan tryphan blue formalin salin (TBFS) dengan perbandingan 1:10 (Ogimoto dan Imai, 1981). Penghitungan dilakukan menggunakan counting chamber dengan ketebalan $0,2 \mathrm{~mm}$ dan luas kotak terkecil o,0625 mm² (jumlah kotak adalah 16x16 buah). Setelah itu dilakukan penghitungan jumlah protozoa di bawah mikroskop dengan pembesaran 100 kali.

Protozoa/ml cairan rumen dihitung dengan rumus :

$$
\begin{aligned}
& \text { Protozoa/ml cairan rumen }=\frac{1}{0,2 \times 0,0625 \times 16 \times 16} \times 100 \times \mathrm{C} \times \mathrm{FP} \\
& \mathrm{C}=\text { jumlah protozoa terhitung dalam counting chamber } \\
& \mathrm{FP}=\text { faktor pengenceran }
\end{aligned}
$$

Digestible organic matter in the rumen (DOMR) menurut Chen dan Gomes (1995):

DOMR $(\mathrm{kg} / \mathrm{h})=$ konsumsi $\mathrm{BO} \times \mathrm{KCBO} \times 0,65=$ konsumsi $\mathrm{BO} \times \mathrm{KCFBO}$

$0,65=$ perkiraan angka kecernaan fermentatif di dalam rumen

Produksi mikrobial nitrogen (MN)

$\mathrm{MN}=32 \mathrm{~g} / \mathrm{kg}$ DOMR

Sintesis protein mikroba rumen (SPM)

$\mathrm{SPM}(\mathrm{g} / \mathrm{hari})=\mathrm{MN} \times 6,25$

Absorsi purin $(\mathrm{mmol} / \mathrm{h})=\mathrm{MN}: 0,727$

Ekskresi purin derivat $(\mathrm{mmol} / \mathrm{h})=0,85$ Abs purin + $0,385 \times \mathrm{W}^{\mathrm{O}, 75}$

Ekskresi allantoin $(\mathrm{mmol} / \mathrm{h})=0,85 \mathrm{x}$ ekskresi purin derivate 


\section{Analisis Data}

Data yang diperoleh pada penelitian ini dianalisis dengan sidik ragam. Apabila terdapat hasil yang berbeda nyata $(\mathrm{P}<0,05)$ antar perlakuan, maka analisis dilanjutkan dengan uji kontras ortogonal pada taraf $5 \%$.

\section{HASIL DAN PEMBAHASAN}

\section{Respon Fermentasi Rumen}

Hasil penelitian ini menunjukkan $\mathrm{pH}$ cairan rumen semua perlakuan berada pada kisaran yaitu 6,31-6,70 (Tabl 2). Kisaran pH cairan rumen normal untuk berfungsinya aktivitas di dalam rumen adalah 6-7. Menurut Kamra (2005), pH optimum untuk pertumbuhan mikroba rumen adalah 6-6,9 dan $\mathrm{pH}$ cairan rumen yang normal adalah 6-7 (Chiba, 2009). Menurut Suryani et al. (2015) pemberian hijauan (70) : konsentrat (30) pada sapi bali jantan pertumbuhan, dimana hijauan yang diberikan terdiri dari rumput gajah, jerami padi, gamal dan kaliandra, menghasilkan $\mathrm{pH}$ rumen 5.54 - 5.79. Perubahan $\mathrm{pH}$ dapat mengubah pola fermentasi karena mempengaruhi produksi saliva. Jenis pakan yang diberikan akan mempengaruhi $\mathrm{pH}$ cairan rumen dan hasil fermentasinya.

Tabel 2. Pengaruh perlakuan terhadap respon fermentasi rumen

\begin{tabular}{lrrrr}
\hline \multirow{2}{*}{ Peubah } & \multicolumn{4}{c}{ Ransum Perlakuan ${ }^{1)}$} \\
\cline { 2 - 5 } & \multicolumn{1}{c}{ A } & \multicolumn{1}{c}{ B } & \multicolumn{1}{c}{ C } & \multicolumn{1}{c}{ D } \\
\hline pH Cairan rumen & 6,70 & 6,50 & 6,40 & 6,31 \\
Kadar N-NH (mMol) $^{\prime}$ & 12,66 & 13,25 & 13,79 & 14,66 \\
VFA Total (mMol) & 145,34 & 151,39 & 145,73 & 165,38 \\
VFA partial dalam 100 mMol & & & & \\
Asetat (mMol) & 70,15 & 69,55 & 64,08 & 59,89 \\
Propionat (mMol) & 19,37 & 20,09 & 23,67 & 27,87 \\
Butirat (mMol) & 9,00 & 8,55 & 9,89 & 10,48 \\
Valerat (mMol) & 1,47 & 1,81 & 2,36 & 1,76 \\
Methan (mMol) & 36,58 & 36,21 & 31,28 & 29,73 \\
NGR & 4,55 & 4,33 & 3,54 & 2,90 \\
\hline
\end{tabular}

Keterangan:

$A=$ konsentrat $40 \%$ dan rumput raja $60 \%$

$B=$ konsentrat $45 \%$ dan rumput raja $55 \%$

$\mathrm{C}=$ konsentrat $50 \%$ dan rumput raja $50 \%$

$\mathrm{D}=$ konsentrat $55 \%$ dan rumput raja $45 \%$

Konsentrasi ammonia $\left(\mathrm{NH}_{3}\right)$ di dalam cairan rumen merupakan hasil pemecahan protein yang terkandung dalam ransum. Dalam hal ini kandungan protein ransum meningkat dengan semakin meningkatnya kandungan konsentrat. Dengan demikian maka konsentrasi $\mathrm{NH}_{3}$ dalam cairan rumen juga semakin meningkat. Kadar $\mathrm{NH} 3$ cairan rumen tertinggi diperoleh pada pedet yang mendapat ransum dengan imbangan 55\% konsentrat: $45 \%$ rumpur raja. Sementara pedet sapi bali yang mendapat ransum dengan komposisi $40 \%$ konsentrat dan $60 \%$ rumput raja menghasilkan kadar $\mathrm{NH}_{3}$ cairan rumen terendah yaitu 12,66 $\mathrm{mMol}$ (Tabel 2).
Mikroba rumen untuk pertumbuhannya sangat tergantung pada ketersediaan $\mathrm{N}$ dalam bentuk peptida, asam amino dan $\mathrm{NH}_{3}$ (Russell et al., 1992). Agar tercapai kebutuhan $\mathrm{N}$ dari mikroba ini, maka NRC (1989) merekomendasikan pakan ternak ruminansia mengandung 60-65\% protein kasar (PK) sebagai rumen degradable protein (RDP) dan setengahnya merupakan solubel protein. Menurut McDonald et al. (2002) bahwa kisaran konsentrasi $\mathrm{NH}_{3}$ yang optimal untuk sintesis protein mikroba rumen berkisar 6-21 mMol.

Pola yang hampir sama ditunjukkan oleh kadar VFA total cairan rumen. Kadar VFA total cairan rumen tertinggi terjadi pada pedet sapi bali yang mendapat ransum D dengan perbandingan 55\% konsentrat dan $45 \%$ rumput raja. Kadar VFA total cairan rumen pedet yang mendapat perlakuan D adalah tertinggi 165, 38 $\mathrm{mM}$ dan terendah pada pedet sapi bali yang mendapat ransum A dengan perbandingan 40\% konsentrat dan $60 \%$ rumput raja. Kadar VFA total pada perlakuan A adalah 145,34 mM. Tertingginya kadar VFA total pada perlakuan D disebabkan karena ransum D mengandung konsentrat tertinggi di antara semua perlakuan sehingga kandungan eneri maupun protein ransum perlakuan D menjadi tertinggi. Sebaliknya perlakauan A mengandung konsentrat terendah sehingga kandungan protein dan energi ransum pada perlakuan A juga terendah. Hal ini mengakibatkan konsentrasi VFA total pada pedet yang mendapat ransum A menjadi terendah. VFA merupakan sumber energi utama untuk ternak ruminansia (Owen dan Bergen, 1983; Preston dan Leng, 1987), dan jumlahnya bervariasi (8o-16o mMol) tergantung jenis ransum dan waktu setelah pemberian pakan (Sutardi, 1979).

France dan Dijkstra (2005) melaporkan secara umum proporsi asam asetat : asam propionat : asam butirat pada pemberian lebih banyak pakan serat adalah 70:20:10. Menurut Chiba (2009), pada pemberian pakan hijauan maka perbandingan asam asetat : asam propionat : asam butirat adalah 65\% : 20\% : $12 \%$. Selanjutnya dikatakan, apabila pakan yang diberikan berasal dari biji-bijian, maka perbandingan tersebut menjadi $40 \%: 37 \%$ : 20\%. Semakin tinggi proporsi asam propionate, mengindikasikan ransum tersebut bersifat glukogenik. Dari hasil penelitian ini terlihat semakin tinggi proporsi konsentrat (kea rah ransum D), maka konsentrasi asam propionate semakin tinggi. Artinya semakin tinggi konsentrat dalam ransum, maka energi yang tersedia akan semakin tinggi pula.

Nilai NGR terendah pada pedet sapi bali yang mendapat konsentrat paling banyak (55\%). Semakin randah nilai NGR berarti semakin banyak energi yang tersedia untuk dimanfaatkan oleh ternak sapi baik untuk pertumbuhan maupun peningkatan berat badan. Rendahnya nilai NGR pada sapi yang 
mendapat perlakuan D berhubungan dengan tingginya asam propionat yang dihasilkan. Konsentrasi asam propionate pada perlakuan $\mathrm{D}$ adalah tertinggi yaitu $27,87 \mathrm{mMol}$ dalam $100 \mathrm{mMol}$. Nilai NGR pedet sapi bali dara pada penelitian ini berkisar antara 2,90 - 4,55. Sementara nilai NGR sapi bali jantan penggemukan hasil penelitian Suryani (2012) lebih rendah yaitu 2,25 $-3,01$.

Tabel 3. Sintesa protein mikroba dan populasi protozoa cairan rumen

\begin{tabular}{lrrrr}
\hline \multirow{2}{*}{ Peubah } & \multicolumn{4}{c}{ Ransum Perlakuan ${ }^{1)}$} \\
\cline { 2 - 5 } & \multicolumn{1}{c}{$\mathrm{A}$} & \multicolumn{1}{c}{$\mathrm{B}$} & \multicolumn{1}{c}{$\mathrm{C}$} & \multicolumn{1}{c}{$\mathrm{D}$} \\
\hline DOMR (g/e/h) & 1427,12 & 1483,06 & 1693,73 & 1843,08 \\
Mikrobial Nitrogen (g/e/h) & 45,67 & 47,46 & 54,20 & 58,98 \\
Sintesa protein mikroba (g/e/h) & 285,42 & 296,61 & 338,75 & 368,62 \\
Absorpsi purin (mMol/h) & 62,82 & 65,28 & 74,55 & 81,13 \\
Ekskresi purin derivat (mMol/h) & 67,76 & 70,02 & 77,96 & 83,69 \\
Ekskresi allantoin urin (mMol/h) & 57,59 & 59,52 & 66,27 & 71,14 \\
Efisiensi SPM (g/kg konsumsi BO) & 121,59 & 130,25 & 133,51 & 144,14 \\
Populasi Protozoa (10 $\mathrm{sel} / \mathrm{ml})$ & 3,69 & 3,44 & 4,55 & 3,50 \\
\hline
\end{tabular}

Keterangan:

$A=$ konsentrat $40 \%$ dan rumput raja $60 \%$

$B=$ konsentrat $45 \%$ dan rumput raja $55 \%$

$\mathrm{C}=$ konsentrat $50 \%$ dan rumput raja $50 \%$

$\mathrm{D}=$ konsentrat $55 \%$ dan rumput raja $45 \%$

Semakin tinggi kandungan konsentrat dalam ransum menyebabkan kecermaan bahan organik ransum dalam rumen (DOMR) semakin meningkat. Kecernaan bahan organik ransum dalam rumen untuk pedet sapi bali yang mendapat perlakuan $\mathrm{B}, \mathrm{C}$ dan $\mathrm{D}$ masing-masing 3,92\%, 18,68\% dan 29,15\% lebih tinggi disbanding pedet yang mendapat ransum A (Tabel 3). Lebih tingginya DOMR perlakuan B, C dan D disbanding perlakuan A disebabkan karena ransum perlakuan $\mathrm{B}, \mathrm{C}$ dan $\mathrm{D}$ mengandung lebih banyak konsentrat. Dengan makin banyaknya konsentrat maka degradable nutrien yang ada dalam ransum juga meningkat sehingga menghasilkan DOMR yang lebih tinggi dari pada perlakuan A. Hasil DOMR tertinggi diperoleh pada pedet sapi bali yang diberi ransum dengan imbangan konsentrat $55 \%$ dan rumput raja $45 \%$ yaitu sebesar $1843.08 \mathrm{~g} / \mathrm{e} / \mathrm{h}$ (Tabel 3).

Tingginya DOMR pada perlakuan D mengakibatkan kebutuhan mikroorganisme di dalam rumen terhadap pasokan nutrien terpenuhi, sehingga menghasilkan sistesis protein mikroba (SPM) yang teringgi pula pada perlakuan D yaitu $368,62 \mathrm{~g} / \mathrm{e} / \mathrm{h}$. Angka ini adalah 29,15\% lebih tinggi dibandingkan SPM yang terdapat pada pedet yang mendapat perlakuan A. Dengan terpenuhinya kebutuhan nutrien mikroorganisme di dalam rumen pedet sapi yang mendapat ransum $\mathrm{D}$, maka sapi-sapi yang mendapat perlakuan D menjadi lebih efisien mengubah bahan organic menjadi protein mikroba. Produksi SPM hasil penelitian ini lebih rendah akan tetapi efisiensinya lebih tinggi dibandingkan hasil yang diperoleh Suryani (2012).
Suryani (2012) melaporkan hasil penelitiannya pada sapi bali jantan penggemukan, pemberian $70 \%$ konsentrat dan 30\% hijauan menghasilkan SPM 466,03 - 552,21 g/e/h dengan efisiensi 82,57 - 93,73 $\mathrm{g} / \mathrm{kg}$ konsumsi BO. Wanapat (2000) yang memberikan ransum jerami padi disuplementasi cassava chip memperoleh sintesis protein mikroba $559 \mathrm{~g} / \mathrm{e} / \mathrm{h}$. Apabila jerami padi ditambah cassava chip dan ditambah urea, sintesa protein mikroba menurun menjadi $422 \mathrm{~g} / \mathrm{e} / \mathrm{h}$. Sementara Mullik (2007) yang memberikan ransum rumput pengola pada sapi jantan mendapatkan sintesa protein mikroba $316 \mathrm{~g} / \mathrm{e} / \mathrm{h}$ dengan efisiensi SPM (g/ kg DOM) 71,8. Di lain pihak, Karsli dan Russell (2001) menyatakan sintesis protein mikroba sangat berbeda pada ternak tergantung pakan yang diberikan, dan bahkan pada pemberian pakan yang sama. Pemberian pakan hijauan dan konsentrat menghasilkan sintesa protein mikroba bervariasi 70-279 g MCP/kg DOMR.

Pakan ternak ruminansia biasanya mengandung asam nukleat rendah dan akan difermentasi secara ekstensif oleh mikroba. Asam nukleat yang masuk ke dalam abomasum dan menuju duodenum terutama berasal dari mikroba rumen. Mikroba rumen kaya akan asam nukleat dimana $18 \%$ dari total $\mathrm{N}$ mikroba dalam bentuk asam nukleat atau $11 \%$ dalam bentuk purin. Purin asam nukleat ini akan dimetabolisme dan diekskresikan lewat urin dalam bentuk derivatnya yaitu allantoin, asam urat, xantin, dan hipoxantin (Chen dan Gomes, 1995). Allantoin urin sangat potensial dipergunakan untuk menduga produksi protein mikroba (Lamothe et al., 2002). Tingginya ekskresi produk derivate purin dan asam nukleat ini megindikasikan tingginya produksi sintesis protein mikroba (Tabel 3).

Populasi protozoa dalam cairan rumen pedet sapi bali calon induk ini berkisar dari 3,44-4,55 $\left(10^{6} \mathrm{sel} / \mathrm{ml}\right.$ cairan rumen). Sementara Suryani (2012) mendapatkan pada cairan rumen sapi bali jantan penggemukan lebih sedikit dan berkisar 4,84 - 8,67 $\left(10^{4} \mathrm{sel} / \mathrm{ml}\right.$ cairan rumen).

\section{SIMPULAN}

Berdasarkan hasil penelitian ini dapat disimpulkan bahwa (1) Pemberian ransum dengan perbandingan $55 \%$ konsentrat dan $45 \%$ rumput raja pada pedet sapi bali calon induk meningkatkan fermentasi rumen dengan meningkatnya kadar $\mathrm{NH}_{3}$, VFA total, asam propionat dan menurunkan gas methan dan angka NGR (2) Semakin tinggi proporsi konsentrat (55\%) dalam ransum akan meningkatkan DOMR sehingga meningkatkan sumbangan protein yang berasal dari SPM, (3) SPM teringgi dihasilkan dari ransum dengan proporsi $55 \%$ konsentrat dan $45 \%$ rumput raja yaitu sebesar 368,62 g/e/h. 


\section{DAFTAR PUSTAKA}

Chen, X. B. and M. J. Gomes. 1995. Estimation of Microbial Protein Supply to Sheep and Cattle Based on Urinary Excretion of Purine Derivatives. An Overview of The Technical Details. International Feed Resources Unit. Rowett Research Institute, Bucksburn Aberdeen AB2 9SB, UK.

Chiba, L. I. 2009. Animal Nutrition Handbook. Second Revision. URL: http://www.ag.auburn.edu/ chibale/ animalnutrition.html diunduh 5 Januari 2011.

France, J. and J. Dijkstra. 2005. Volatile Fatty Acid Productions. In: Quantitative Aspect of Ruminant Digestion and Metabolism. 2nd Ed. C. A. B. International, Cambridge, USA.

General Laboratory Procedures. 1966. Department of Dairy Science. University of Wisconsin. Madison.

Kamra, D. N. 2005. Rumen microbial ecosystem. Special Section: Microbial Diversity. Current Science, Vol. 89 No. 1:124-135

Karsli, M. A. and Russell, J. R. 2001. Effect of some dietary factors on ruminal microbial protein synthesis. Turk. J. Vet. Anim. Sci. 25 (2001) 681-686.

http://journals.tubitak.gov.tr/veterinery/issue/vet-01.25.5/ vet-25-5-7-002-14.pdf diunduh 29 Desember 2009.

Kementerian Pertanian - Badan Pusat Statistik. 2011. Rilis Hasil Akhir PSPK 2011.

Lamothe, M., T. Klopfenstein, D. Adams, J. Musgrave and G. Erickson. 2002. Urinary Allantoin as an Estimate of Microbial Protein Synthesis. Animal Science Department. Nebraska Beef Cattle Reports. University of Nebraska - Lincoln.

McDonald, P., R. A. Edwards, J. F. D. Greenhalgh, and C. A. Morgan. 2002. Animal Nutrition. 6th Ed. Pretice all, London.

Mullik, M. L. 2007. Efficiency of Microbial Protein Synthesis in Steer Fed Freshly Harvested Tropical Grass. Conference on International Agricultural Research for Development, October 9-11. University of KasselWitzenhausen and University of Gottingen. Tropentag. http://www.Tropentag.de/links/Mullik_21whzXzh. pdf diunduh 15 Juni 2010.

National Research Council (NRC). 1989. Nutrient Requirement of Dairy Cattle. National Academy Press, Washington DC. USA.
Ogimoto, K. And S. Imai. 1981. Atlas of Rumen Microbiology. Japan Scientifict Societies Press, Tokyo.

Orskov, E. R. 1982. Protein Nutrient in Ruminant. Academic Press. London.

Orskov, E. R. And Ryle. 1990. Energy Nutrition in Ruminant. Elsevier Applied Science. London.

Owens, F. H. and W. G. Bergen. 1983. Nitrogen metabolism of ruminant animals: Historical perspective, current understanding and future implication. J. Anim. Sci. 57, suppl 2.

Preston, T. R. and R. A. Leng. 1987. Matching Ruminant Production Systems with Available Resources in the Tropics and Sub-tropics. Perambul Books Armidale.

Russell, J. B., R. E. Muck and P. J. Weimer. 2009. Quantitative analysis of cellulose degradation and growth of cellulolytic bacteria in the rumen. FEMS Microbiol. Ecol. 67:183-197.

Russell, J. B., J. D. O’Connor, D. G. Fox, P. J. Van Soest, and C. J. Sniffen. 1992. A net carbohydrate and protein system for evaluating cattle diets: I. Ruminal fermentation. J. Anim. Sci. 70:3551-3561.

Solorzano Lucia. 1969. Determination of ammonia in natural waters by the phenol hypochlorite method. Limnology and Oceanography. Vol. 14 (5) : 799-801. American Society of Limnology and Oceanography.

Steel, R. G. D. Ang J. H. Torrie. 1986. Priciples and Procedures of Statistic. McGraw-Hill Book Co. Inc., New york.

Suryani, N. N. 2012. Aktivitas Mikroba Rumen dan Produktivitas Sapi Bali yang Diberi Pakan Hijauan dengan Jenis dan Komposisi Berbeda. Disertasi. Program Pascasarjana, Universitas Udayana Denpasar.

Suryani, N.N., I G. Mahardika, S. Putra, dan N. Sujaya. 2015. Pemberian Gamal Tambahan dalam Ransum Meningkatkan Neraca Nitrogen dan Populasi Mikroba Proteolitik Rumen Sapi Bali. J. Vet. 16 (1): 117-123.

Suryani, N. N., K. M. Budiasa dan I P. A. Astawa. 2013. Suplementasi Gamal sebagai rumen degradable protein (RDP) untuk meningkatkan kecernaan (in vitro) ransum ternak ruminansia yang mengandung jerami padi. Maj. Ilmiah Peternakan 16 (1): 1-5.

Sutardi, T. 1979. Ketahanan Protein Bahan Makanan terhadap Degradasi oleh Mikroba Rumen dan Manfaatnya bagi Peningkatan Produktivitas Ternak. Pros. Seminar Penelitian Penunjang Peternakan, LPP. Bogor. 